\title{
Władimir KAPICYN
}

Moskiewski Uniwersytet Państwowy im. M. Łomonosowa

kapizin@yandex.ru

\section{PRZEMIANY TOŻSAMOŚCI POSTRADZIECKICH W ROSJI}

\section{ABSTRACT Changes of post-Soviet identities in Russia}

Having introduced the term ,identifying method”, the author deals with changes of social and political identities in post-Soviet Russia. Referring to cognitive model, comprising horizontal and vertical, as well as domestic and external components of national identity the paper analyzes the ways of perceiving the term "post-Soviet identity”. Two parts are discerned in the sphere of joining national identity: modified axiological core and protective „covering”.

Keywords: identity, identifying method, national identity, Soviet and post-Soviet identity, modelling

Słowa kluczowe: tożsamość, metoda konstruowania tożsamości, tożsamość narodowa, tożsamość radziecka i postradziecka, modelowanie 
$\mathrm{O}$ znaczeniu tożsamości, zwłaszcza narodowej, jej związku z integralnością społeczeństwa świadczą zachodzące w ogromnej skali przemiany współczesnych społeczeństw. Wokół pojęcia tożsamości toczy się wiele sporów, wynikających z kilku przyczyn. Pierwszy powód - epistemologiczny - to trudność zrozumienia istoty na podstawie jej przejawów (tożsamości to jedno z najbardziej tajemniczych zjawisk). Drugi powód - logiczny - tożsamości są wielowymiarowe, istnieje wiele ich manifestacji, a w związku z tym - różne podejścia do zakresu i treści tego pojęcia ${ }^{1}$. Trzeci powód związany jest tranzytywnością (zmiennością) społeczeństwa. Jaki jest związek tożsamości ze zmianami społecznymi? Niektórzy uważają, że tożsamość narodowa jest wielkością niemal niezmienną, ściśle związaną z duchem i duszą narodu, jego pochodzeniem. To podejście prymordialne (primordialis, łac. - początkowy, wrodzony). Drugie podejście - konstruktywistyczne - zakłada „płynność” tożsamości, możliwość konstruowania ich w taki sposób, jaki jest niezbędny dla różnych podmiotów. Konstruktywizm zyskał duży wpływ w społeczeństwie informacyjnym w dobie globalizacji.

Rzeczywistość potwierdza znaczenie etnosu i terytorium w kształtowaniu tożsamości, na co zwracają uwagę zwolennicy prymordializmu. Jednak w szeregu przypadków tożsamości tworzone są jako konstrukty sztucznie wkomponowane w postrzeganie rzeczywistości, wprowadzane do świadomości (i nieświadomości) ludzi poprzez obrazy, symbole, mity polityczne, aktualizowane na mitingach, filmy, programy w środkach masowego przekazu, propagandę, reklamy. W reklamie codziennej, z reguły, obecnych jest wiele elementów o charakterze eklektycznym, znamionujących elementarny braku gustu. Świadczą o tym, na przykład, nazwy różnych organizacji handlowych ${ }^{2}$. Jest to możliwe również w polityce, gdy obce konstrukty są włączane do narracji narodowej (long narrativ): zjawiska odosobnione, przypadkowe są przedstawiane jako masowe i trwałe bądź niezadowolenie małej części ludności jest pokazywane jako ruch całego narodu. Fikcyjne zdarzenia trafiają do podręczników historii, na wystawy muzealne, do „instytutów pamięci”, przedstawiane są szerokiej publiczności.

Budowanie tożsamości (идентификации) ${ }^{3}$ to proces naturalny, dlatego zauważamy go wtedy, gdy coś jest nie tak, gdy następuje kryzys tożsamości. W dobie glo-

1 Na przykład słownik Siergieja Krawczenki zawiera 13 terminów z frazą „konstruowanie tożsamości” („идентификация”) i 16 ze słowem „tożsamość” („идентичность”). Zob.: C. Кравченко, Социологический энииклопедический русско-английский словарь. Sociological Encyclopedic Russian-English Dictionary, Москва 2004, s. 128-130. W Stownikuterminów ipojęćtożsamości opisano izidentyfikowano ponad 40 kombinacji. Zob. Политическал идентичность и политика идентичности. В 2-х томах, red. И. Семененко, t. 1: Идентичность как категория политической науки. Словарь терминов и понятий, Москва 2012.

2 W Moskwie w treściach bannerów eklektycznie łączą się elementy różnych kultur, zupełnie nie odpowiadając ani charakterowi reklamowanej organizacji, ani specyfice narodowej tożsamości: Galabank, Grand Grill, Kebab House. Bistro, centrum biznesowe Borodino Plaza, restauracja Genacvale Hall. Zob. М. Попов, Москва рекламная. О,ляпах” на московскихрекламных плакатах и выьвесках, „Московский журнал. История государства Российского” 2014, nr 11, s. 77-84.

3 Autor posługuje się terminami: „идентичность” (w przekładzie oddawany jako „tożsamość”) oraz „идентификакция” (w tłumaczeniu: „konstruowanie tożsamości”). Redakcja dziękuje prof. Andrzejowi Porębskiemu za konsultację terminologiczną [przypis Redakcji]. 
balizacji kryzys tożsamości staje się powszechny, co oznacza swego rodzaju „stan płynny" orientacji wartościujących społeczeństwa ${ }^{4}$. To zmusza do ciągłego aktualizowania konceptów rosyjskiej tożsamości narodowej i metod jej konstruowania (идентификационный метод), aby zachować heurystyczne możliwości ujęć teoretycznych. Istota metody konstruowania tożsamości polega na analizie tego, jak człowiek i grupy społeczne (organizacje) postrzegają współoddziaływanie samoorganizacji życiowej sfery ludzi i procesu politycznego, organizacji politycznych, państwa, społeczności globalnej i tego, w jaki sposób konstruują tożsamości życiowe (obywatelskie) i narodowe.

Aby pogłębić wyobrażenie o metodzie budowania tożsamości, rozważymy strukturę tożsamości narodowej i jej elementy w odniesieniu do procesu zmiany tożsamości na linii ZSRR-Rosja. W tym celu stworzymy model (konstrukt, obraz, schemat) kognitywny (poznawczy), odzwierciedlający procesy rzeczywiste i zarazem naoczny. Elementy takiego modelu można dostrzec u francuskiej konstytucjonalistki Marie-Claire Ponthoreau: Tożsamość narodowa opiera się, z jednej strony na czynnikach obiektywnych, takich jak jezyk, religia, kultura, grupa etniczna, a z drugiej - na czynnikach subiektywnych, między innymi, na poczuciu przynależności, wspótudziatu, i pozostaje w relacji zobywatelskością, suwerennościa i państwowościas.

Przy pomocy takiego modelu można bardziej szczegółowo przedstawić strukturę i elementy tożsamości narodowej:

1) Jako jej podstawowe elementy wyróżniane są tożsamości „częściowe” i ich konfiguracje.

2) Model odzwierciedla interakcje tożsamości „wewnętrznych” i „zewnętrznych”, które wpływają na kształtowanie i zmianę konfiguracji wyrażających tożsamość narodową.

3) Model tworzy naoczne wyobrażenie niedostępnych dla ludzkiego postrzegania (wzroku, słuchu) procesów konstruowania tożsamości, dzięki wyodrębnieniu znaków i symboli, oznaczających (wizualizujących, udźwiękowiających) i kodujących wartości i sensy lokowane w tożsamości.

4) W tożsamości narodowej wyodrębniane są składowe: państwowa lub polityczna (utożsamianie się z władzą państwową, jej instytucjami i symbolami - granicą, wojskiem, głową państwa, parlamentem etc.); obywatelska lub społeczna (utożsamianie się ze społecznością, sukcesami kraju w rozwoju nauki, kultury, gospodarki, sportu). W polityce tożsamości ważne jest, aby owe sposoby konstruowania tożsamości zbliżały się w celu konsolidacji, integralności społeczeństwa i dobrobytu państwa. Rozbieżność między nimi oznacza kryzys tożsamości narodowej. Może to prowadzić do przesunięcia środka ciężkości systemu konstruowania tożsamości człowieka, np. w stronę osiągnięć sportowych kraju. Może

В. Аипкин, Кризис идентичности, [w:] Политическая идентичность и политика идентичности..., t. 1, s. 44 .

5 М.-К. Понторо, Европейскал Конститущия и нащиональныце конститущионные идентичности (Реферат), [w:] Конститущионная культура. Универсальньце ценности и национальнье особенности, red. Е. А^ферова і in., Москва 2011, s. 147, Правоведение. 
również prowadzić do destabilizacji społecznej i turbulencji, grozić podziałem narodu, jak miało to miejsce na Ukrainie na początku 2014 r.

W zaproponowanym modelu przeanalizujemy tożsamości „wewnętrzne”, grupujące się w dwóch „małych” konfiguracjach. Model łączy tożsamości „wewnętrzne” w dwóch składowych - codziennej (społecznej) i politycznej. Łączą się one w „dużej” konfiguracji - tożsamości narodowej. Dla unaocznienia wykorzystamy ujęcia wymiaru „poziomego" $\mathrm{i}$ „pionowego". Jest to przydatne w następującym wyobrażeniu metaforycznym: tożsamość narodowa „utkana” jest jak „płótno”, w którym nici („częściowe” tożsamości) przeplatają się prostopadle. Jedne - „poziomo” (tożsamość społeczna), drugie „pionowo" (tożsamość polityczna). Tak powstaje „płótno” („dywan”) - tożsamość narodowa z unikalnym „wzorem”, szyfrującym kod aksjologiczny danego narodu za pomocą kompleksów symboli.

Tożsamość społeczna, składająca się z tożsamości poziomych, postrzegana jest przez człowieka jako suma wyobrażeń i uczuć, jako znaczące podobieństwo pomiędzy tym, jak chce on ujrzećs sam siebie, i tym, czego, wedtugjego wyostrzonych zmystów, oczekują od niego inni $i^{6}$. Kształtuje się ona już od poziomu ciągłych, codziennych aktów mentalnych i werbalnych oraz praktyk (wyznaczenie zadań, ocena działań, realizacja planów). Prowadzi to do ukształtowania „pól” konstruowania tożsamości poziomej (związanej ze sferą życiową) jako podstawy matrycy godności człowieka. W abstrakcyjnym modelu idealnym do tożsamości poziomych można zaliczyć: tożsamość terytorialną (środowiskową [природная]), naturalną (cielesną), duchową (kulturową), czynnościową (zawodową).

Tożsamość terytorialna wyrażona jest w mentalnym związku ludzi z klimatem i krajobrazem terytorium, zasobami naturalnymi, formą osadnictwa, środkami komunikacji (wartości: dostępność i bezpieczeństwo transportu, ochrona przyrody). Tożsamość naturalna przejawia się w sposobie odżywiania, zamieszkiwania, w codzienności, charakterze rodziny - w relacjach małżeńskich i rodzicielskich, infrastrukturze służby zdrowia (wartości: zdrowie, miłość i wzajemny szacunek małżonków, dzieci i rodziców, sąsiedztwo). Tożsamość duchowa wyraża się w poszanowaniu pierwiastków sakralnych, skarbów literatury narodowej, sztuki, wychowania i edukacji (wartości: miejsca kultu, pamięć o bohaterach, pomniki historii i kultury). Tożsamość czynnościowa przejawia się w gospodarczej żywotności ludności - w rzemiośle i ludowej przedsiębiorczości, w gospodarce lokalnej, mistrzach-profesjonalistach, kolektywach pracowniczych, które odniosły sukces (wartości: pracowitość, współpraca, współzawodnictwo, bezpieczeństwo pracy). Wszystkie te wartości składają się na treść tożsamości społecznej i włączają się do tożsamości narodowej. Przykładowo nie może istnieć tożsamość narodowa Rosji bez jej rozległego terytorium, zasobów naturalnych, złóż kopalin, lasów, zwierząt, zasobów rybnych Morza Kaspijskiego, Dalekiego Wschodu, Wołgi, Jeniseju, Amuru?

\section{Э. Эриксон, Молодой Аютер, Москва 2004, s. 34.}

Por. А. Анастасьев, Повесть о рыбаках и рыбе, „GEO. Неопознанный мир: Земля” 2013, nr 188, s. 88-105. 
Analiza wieloaspektowej samoorganizacji życia codziennego pozwala na jej wizualizację za pomocą modelu mechanizmu strukturyzacji, definiującego matrycę godności odzwierciedlającego działalność ludzi. „Pola” samoorganizacji i życiowych konstrukcji tożsamości odzwierciedlają kanały w codziennych poziomych interakcji ludzi w społeczeństwie, ukierunkowujące ich aktywność kognitywną (poznawczą) i socjalizację. Dla „radzieckiej” i „postradzieckiej” tożsamości narodowej zarówno typy konfiguracji i zestaw konstruowanych tożsamości, jak i sposoby ich przejawiania się są różne. W związku z tym różnią się matryce godności człowieka. Być może tożsamość radziecką lepiej byłoby nazwać ponadnarodową, posługujemy się jednak ogólną kategorią „tożsamości narodowej".

Wyodrębnianie „pól” konstruowanej tożsamości poziomej, odzwierciedlanych w koncepcie tożsamości narodowej („radzieckiej”), ujawnia tożsamość naturalną, duchową i czynnościową. Cechy takiego zestawu tożsamości to: 1) niewyrażalność „pola” konstruowania tożsamości terytorialnej (lokalnej) (jest ono „rozpuszczone” w „polu” konstruowania tożsamości naturalnej, co znalazło wyraz m.in. w braku praktyki samorządności lokalnej); 2) słaby wyraz konstrukcji tożsamości naturalnej, w odróżnieniu od dwóch innych „pól” budowania tożsamości. Rzeczywiście w radzieckiej codzienności myślano bardziej kategoriami „szkoły”, „wychowania komunistycznego” i „kolektywu pracowniczego”. Znacznie mniej zauważalny jest dyskurs pojęć „rodzina”, nawet w bezpośrednim odniesieniu do szkoły; w jeszcze mniejszym stopniu wyrażone są pojęcia „miejsce”, „mieszkaniec”.

Oprócz konstruowania tożsamości poziomej w sferach życiowych człowiek identyfikuje siebie i swoją grupę także w systemie pionowych współrzędnych. Sfery życiowe, w których człowiek wykonuje codzienne czynności i podejmuje decyzje, mimo zwyczajności, są aktywnie werbalizowane, symbolizowane i otwierają przejście na poziom życia politycznego, a poprzez nie - na sferę zarządzania municypalnego i państwowego. W naszym rozumieniu życie polityczne to „bufor” pomiędzy sferami życia („polami” budowania tożsamości poziomej) i polityką państwa. Jest on stale wypełniany sygnałami z codzienności, z konstruowanych tożsamości poziomych, uzyskujących spolityzowany charakter. Do „bufora” trafiają wyobrażenia, porzucające „pola” konstrukcji tożsamości poziomej, przechodzące w stan symboli niezadowolenia i żądań politycznych. Proces ten pozostaje pod wpływem zbiorowości i polityki państwa. Przepełnienie owego „bufora” symbolami upolitycznionego niezadowolenia ludzi jest postrzegane jako „wybuchy” aktywności społecznej i przejście mas na poziom polityki państwa, jako destabilizacja sytuacji politycznej. Zbiorowość („bufor” - życie polityczne) pośredniczy w interakcji konstrukcji tożsamości poziomych i pionowych.

Tożsamości pionowe odzwierciedlają w świadomości ludzi kanały (sposoby) reprezentowania i ochrony interesów oraz praw jednostek, jeśli nie można ich bronić w codzienności. W świadomości i nieświadomości zostają odtworzone wyobrażenia i nawyki dotyczące tego, jak działają ludzie, wyrażając swoje prawa i interesy i broniąc ich. Ludzie

А. Акмалова, Особенности правового регулирования и организации местного самоуправления в Российской Федерации (теоретико-методологический аспект). Аиссертация на соискание степени доктора юридических наук, Москва 2003. 
wychodzą poza granice codzienności, żeby zgłosić roszczenia władzom, kształtować sposoby przedstawiania roszczeń i sposoby ochrony praw i interesów. Działają nie tylko osobiście (indywidualnie), lecz także drogą łączenia (dzielenia) wysiłków jednostek i grup, przy pomocy państwa (deputowani, policja, sądy, prokuratura, inspekcja pracy etc.), przy pomocy społeczności międzynarodowej (organizacje międzynarodowe).

Dlaczego pojawiają się wspomniane tożsamości pionowe? Ludzie nie chcą przecież angażować się w politykę, kontaktować się z urzędnikami, wolą spokojne życie codzienne. Nie zawsze jednak udaje się pozostać w takim spokoju. W sferze codzienności mogą się pogarszać warunki życia (komunikacja, ekologia, usługi komunalne, jakość żywności, opieka medyczna, może rosnąć przestępczość uliczna, może ulegać deformacji edukacja szkolna, wzrastać bezrobocie i przestępczość, psuć się bezpieczeństwo pracy). Nie zawsze można rozwiązać te problemy, zwracając się do dyrektora przedsiębiorstwa transportowego, firmy zanieczyszczającej środowisko, administratora (zarządcy budyn$\mathrm{ku}$ ), naczelnego lekarza, dyrektora szkoły, pracodawcy. Ludzie są podzieleni palisadą prywatnych interesów. Jak pokonać tę „palisadę”?

Tożsamość społeczna nie jest „utwierdzana” w ramach codzienności, wychodzi poza jej granice do sfery kolizji interesów, określanej mianem „życia politycznego”. Życie polityczne jest tworzone nie tylko pod wpływem codzienności, „od dołu” „Od góry” na ów „bufor” oddziałuje polityka państwa i ideologia. Erik Erikson uważał, że ideologia jest konieczna, aby $w$ określonym czasie dostosować fakty do idei $i$ idee do faktów, $w$ celu stworzenia obrazu świata wystarczająco przekonującego dla utrzymania tożsamości zbiorowej i indywidualnej ${ }^{9}$. W ZSRR w latach 80 . i 90. liczne ruchy społeczne i narodowe, zaczynając od żądań rozwiązania kwestii ekologicznych lub zwiększenia udziału języka narodowego w życiu codziennym, przechodziły do żądań dymisji rządu, rozwiązania partii rządzącej, niepodległości narodowej i wyjścia ze składu ZSRR ${ }^{10}$.

W taki sposób kształtują się tożsamości pionowe. W idealnym wariancie tożsamości narodowej występują konstrukcje tożsamościowe indywidualne, zbiorowe, państwowe, międzynarodowe. Dzięki tożsamości indywidualnej (wartości: wolność, niezależność) człowiek (obywatel), będąc świadomy swoich interesów i praw osobowych, broni ich samodzielnie. Tożsamość zbiorowa (wartości: solidarność, zorganizowanie) jest kształtowana przy pomocy zrzeszeń społecznych. Tożsamość państwowa - mocarstwowa (wartości: egalitaryzm, bezpieczeństwo narodowe) oznacza ochronę rodaków, socjalne zabezpieczenie obywateli, służenie interesom narodowym. Tożsamość internacjonalna - międzynarodowa (wartości: „współpraca międzynarodowa”, „nieingerencja w wewnętrzne sprawy państw”, „prawa człowieka”) zakłada ochronę interesów i praw przy pomocy wspólnoty międzynarodowej i organizacji międzynarodowych.

Tożsamość narodowa („radziecka”) miała swoje szczególne cechy w odniesieniu do życia politycznego. W radzieckim rozumieniu życie polityczne (działalność partyjna i społeczna, społeczność) oraz polityka państwa sensu stricto zlewały się w jedno. Dzia-

Э. Эриксон, Молодой Аютер..., s. 48.

10 Э. Ян, Государственная трансформачия на востоке Европьь, [w:] Национализм в поздне- и посткоммунистической Европе, red. Э. Ян, Москва 2010, s. 18. 
łalność partyjna i społeczna były podporządkowane polityce państwa (można również odczytywać to na odwrót: monopolityka partii rządzącej podporządkowywała sobie politykę państwa). Dominowały „pola” konstrukcji pionowej: „,egalitaryzm państwowy” („kraj”, „państwo”, ideologia „budowniczych komunizmu”), jak również „solidarność zbiorowa” i „międzynarodowy (proletariacki) internacjonalizm”. Słabo było wyrażone pole „indywidualizmu”. W zamkniętym społeczeństwie radzieckim bezpieczeństwo narodowe było ściśle związane z ograniczeniem napływu informacji z zagranicy, ze zmniejszeniem kontaktów transgranicznych. Jednocześnie internacjonalizm proletariacki, ze wszystkimi jego względnymi ograniczeniami, był jednym z ideologicznych filarów tożsamości radzieckiej. Biorąc pod uwagę zmiany w strukturze społecznej w wielu krajach, wzrost politycznego znaczenia średnich klas, a także stosunkowo niewielką liczebność klasy robotniczej w krajach rozwijających się, europejskie partie komunistyczne proponowały poszerzenie tego pojęcia w postaci „nowego internacjonalizmu".

konstruowanie tożsamości w sferze działaniowo-zawodowej

konstruowanie tożsamości w sferze duchowo-kulturowej

konstruowanie tożsamości w sferze przyrodniczo-antropologicznej

konstruowanie tożsamości w sferze terytorialno-przestrzennej

Rys. 1. Poziome konstruowanie tożsamości w postradzieckiej tożsamości narodowej - wariant idealny

Jeden ze wskaźników tożsamości narodowej (radzieckiej) stanowi wyobrażenie potrzeb i możliwości zajęcia przez człowieka godnego miejsca w życiu, wyobrażenia o swojej godności właśnie w środowisku pracy - jako pracownika socjalistycznego, a w sferze duchowej - jako kompetentnego i ideowego obrońcę interesów narodowych (radzieckiego patriotę). W taki sposób w tożsamości narodowej (radzieckiej) pojawia się matryca godności, eksponowana w symbiozie działalności partyjnej (oraz społecznej) i państwowej polityki KPZR.

Mówiąc o tożsamości narodowej (postradzieckiej), wyróżniamy dwa modele: wariant idealny i wariant realny, który ukonstytuował się w realnym życiu w latach 90. $\mathrm{Z}$ dużym trudem staramy się go przezwyciężyć, przekształcić, naprawić w XXI w. W tożsamości narodowej - postradzieckiej (wariant idealny), ukształtowanej sztucznie, poprzez bezpośrednie zapożyczenia wyobrażeń zachodnich, obecne są konfiguracje „pól” konstrukcji poziomej.

W założeniu, jak widzimy na rys. 1, te „pola” ujawniają szerszy i bardziej równomiernie przejawiający się zestaw „pól” poziomych konstrukcji tożsamości, ich współzależność i równowagę. Zauważalna jest obecność „pola” terytorialno-przestrzennego, sposobu konstruowania tożsamości, którego nie ma w tożsamości narodowej (radzieckiej). 
Ale w realnym modelu tożsamości narodowej (postradzieckiej) można zauważyć znaczącą nierównowagę tożsamości poziomych. Dominuje tożsamość terytorialna i działaniowa, podczas gdy naturalna i duchowa przejawiają się znacznie słabiej. Jest to spowodowane intensyfikacją „walki o byt”, ostrą konkurencją na rynku pracy i w rozwoju kariery, migracją siły roboczej za granicę, napływem migrantów zarobkowych. Daje się zauważyć aktywizacja tożsamości terytorialnej dzięki budowaniu samorządu lokalnego, tworzeniu wspólnot mieszkaniowych, wyborom zarządzających nimi firm, rynkowi nieruchomości itp. Oczywiście wszystko to następuje w sposób daleki od optymalnego, czasem wręcz karykaturalnie, ale w porównaniu z tożsamości radziecką widać zmiany.

W życiu politycznym kształtują się nie tylko tożsamości pionowe, ale dochodzi również do zintegrowania tożsamości społecznej i politycznej. Sposób, w jaki powstaje to połączenie, określa kultura polityczna społeczeństwa. Może to być odwołanie się do sądu, udział w demonstracji pokojowej, reprezentacja interesów przez stowarzyszenie społeczne, związki zawodowe, partię polityczną, parlamentarzystę, organizację międzynarodową. Możliwe są także zamieszki, przeradzające się w pogromy, podpalenia, pobicia policjantów i żołnierzy wojsk wewnętrznych, co czyniła nieprzejednana opozycja w Kijowie w styczniu 2014 r.

Idealny model tożsamości narodowej, realizowany w szeregu krajów europejskich, znacznie różni się od rzeczywistego modelu tożsamości narodowej (postradzieckiej). Różnice te są wyrażone w stosunku „pól” pionowej konstrukcji tożsamości, reprezentujących w życiu politycznym żądania ludzi, aby zapewnić im określone zasoby: dobra, warunki, prawa (terytorialne, naturalne, duchowe, działaniowe), gwarancje, informacje itd. W miejsce internacjonalizmu pojawia się w tym przypadku takie "pole” konstrukcji pionowej, jak „globalny uniwersalizm”.

\begin{tabular}{|c|c|c|c|} 
& & $\mathrm{k}$ & \\
$\mathrm{g}$ & $\mathrm{p}$ & $\mathrm{o}$ & $\mathrm{p}$ \\
$\mathrm{l}$ & $\mathrm{a}$ & $\mathrm{l}$ & $\mathrm{r}$ \\
$\mathrm{o}$ & $\mathrm{n}$ & $\mathrm{e}$ & $\mathrm{y}$ \\
$\mathrm{b}$ & $\mathrm{k}$ & $\mathrm{w}$ \\
$\mathrm{a}$ & $\mathrm{t}$ & $\mathrm{t}$ & $\mathrm{a}$ \\
$\mathrm{l}$ & $\mathrm{w}$ & $\mathrm{y}$ & $\mathrm{t}$ \\
$\mathrm{n}$ & $\mathrm{o}$ & $\mathrm{w}$ & $\mathrm{n}$ \\
$\mathrm{y}$ & $\mathrm{w}$ & $\mathrm{y}$ \\
& $\mathrm{y}$ & $\mathrm{y}$ & \\
uniwersalizm & egalitaryzm & solidaryzm & indywidualizm
\end{tabular}

Rys. 2. Pola pionowego konstruowania tożsamości w tożsamości narodowej (postradzieckiej) - wariant idealny

Tożsamość narodowa (postradziecka) w założeniu dąży do przejęcia atrybutów zachodnich wyobrażeń i „pól” konstruowania tożsamości. W rzeczywistości wprowadzenie zachodniej matrycy godności ludzkiej nie może odbywać się sprawnie, biorąc pod 
uwagę różne kody cywilizacyjne. W pewnych warstwach ludności zachowana jest tożsamość „radziecka” (25-30\% badanych). Realnie tożsamość narodowa (postradziecka) różni się od zachodniego modelu życia politycznego i konfiguracji „pól” budowania tożsamości. W tożsamości narodowej - postradzieckiej (model realny) pola są wyrażone nierównomiernie; dominują skrajne, a centralne są osłabione. Osłabione są "pola" konstruowania tożsamości: „egalitaryzm państwowy” i „solidaryzm kolektywny”, a pola: „indywidualizm prywatny” i „globalny uniwersalizm” - przeciwnie - są wyrażone znacznie mocniej (rys. 3).

\begin{tabular}{|c|c|c|c|}
\hline $\begin{array}{l}\mathbf{G} \\
\mathbf{L}\end{array}$ & $\begin{array}{l}\mathbf{e} \\
\mathbf{g}\end{array}$ & $\begin{array}{l}\mathbf{s} \\
\mathbf{0} \\
\end{array}$ & $\begin{array}{l}\mathbf{P} \\
\mathbf{R} \\
\end{array}$ \\
\hline \multicolumn{4}{|c|}{ DZIAŁANIOWE KONSTRUOWANIE TOŻSAMOŚCI } \\
\hline $\begin{array}{l}\mathbf{O} \\
\mathbf{B}\end{array}$ & $\begin{array}{l}\mathbf{a} \\
\mathbf{l}\end{array}$ & $\mathbf{I}$ & $\begin{array}{c}\mathbf{Y} \\
\mathbf{W}\end{array}$ \\
\hline \multicolumn{4}{|c|}{ konstruowanie tożsamości w sferze duchowej } \\
\hline $\begin{array}{l}\mathbf{A} \\
\mathbf{L}\end{array}$ & $\begin{array}{l}\mathbf{i} \\
\mathbf{t}\end{array}$ & $\begin{array}{l}\mathbf{d} \\
\mathbf{a}\end{array}$ & $\begin{array}{l}\mathbf{A} \\
\mathbf{T}\end{array}$ \\
\hline \multicolumn{4}{|c|}{ konstruowanie tożsamości w sferze przyrodniczej } \\
\hline $\begin{array}{l}\mathbf{I} \\
\mathbf{Z}\end{array}$ & $\begin{array}{l}\mathbf{a} \\
\mathbf{r}\end{array}$ & $\begin{array}{l}\mathbf{r} \\
\mathbf{y}\end{array}$ & $\begin{array}{l}\mathbf{Y} \\
\mathbf{Z} \\
\end{array}$ \\
\hline \multicolumn{4}{|c|}{ TERYTORIALNE KONSTRUOWANIE TOŻSAMOŚCI } \\
\hline $\mathbf{M}$ & $\begin{array}{l}\mathbf{y} \\
\mathbf{z} \\
\mathbf{m}\end{array}$ & $\begin{array}{l}\mathbf{Z} \\
\mathbf{m}\end{array}$ & M \\
\hline
\end{tabular}

Rys. 3. Tożsamość narodowa (postradziecka) - wariant realny

Charakteryzując dynamikę realnego wariantu tożsamości postradzieckiej, można zastosować metaforę „rdzenia” aksjologicznego i „otoczki” ochronnej. „Rdzeń” charakteryzuje stabilność kodu aksjologicznego narodu, jest odpowiedzialny za „historyczność” (ciągłość) tożsamości narodowej. „Otoczka” jest bardziej zmienna i elastyczna. Czym jest „rdzeń” aksjologiczny? W tym kontekście można odwołać się do terminu „patriotyzm", traktowanego jako twór duchowy. Treść tego pojęcia oddaje określenie Hegla: patriotyzm - to stan umystu, gotowość oddania swojego majątku i życia dla catości narodu, tym większa, im bardziejposzczególny cztowiek może dziatać dla wspólnej sprawy z wtasnej woli $i$ samodzielnie $i$ im większym zaufaniem darzy państwo ${ }^{11}$. Hegel wyodrębnia dwie składowe patriotyzmu - państwową („zaufanie do państwa”) i obywatelską („dla całości narodu” - miłość do własnej kultury, ziemi, ojczyzny). To prowadzi nas do wyodrębnienia patriotyzmu jako aksjologicznej podstawy tożsamości narodowej ${ }^{12}$.

„Otoczka” zapewnia możliwość adaptacji tożsamości narodowej do zmieniających się okoliczności. Jej relacje z różnymi rodzajami tożsamości charakteryzuje stopień

\footnotetext{
11 Г. В. Ф. Гегель, Работы разных лет. В двух томах, wybór i red. А. Гулыга, t. 2, Москва 1971, s. 70.

12 И. Аысак, И. Наливайченко, Патриотизм: отжившал ценность или актуальньй тренд, Таганрог 2013, s. 38-40.
} 
„otwartości” na wplywy zewnętrzne, na idee i tożsamości innych państw i organizacji. Zarówno „rdzeń”, jak i „otoczka” są niezbędne do zapewnienia integralności społeczeństwa. Taka struktura jest uniwersalna dla różnych społeczeństw, lecz w każdym z nich tożsamość narodowa różni się pod względem treści, charakteru relacji „rdzenia” i „otoczki”, a tym samym - charakteru patriotyzmu. Tożsamość narodowa, a wraz z nią i wiara w państwo, „obraz wspólnoty”, poddawane są naciskom, z jednej strony - od „wewnątrz” przez partykularne (indywidualne i grupowe) tożsamości obywateli, z drugiej strony - przez tożsamości „zewnętrzne” (kosmopolityczne i inne). „Otoczka” neutralizuje wpływ zmian proporcji między wartościami „wewnętrznymi” i „zewnętrznymi” (nierzadko obcymi), aby zachować „rdzeń” w normalnym stanie. Jeśli zmiany w „rdzeniu” są mimo wszystko nieuniknione, „otoczka” wspomaga stopniową zmianę, absorbując kontrtożsamości, tworzone przez połączenie tożsamości „wewnętrznych” $\mathrm{i}$ „zewnętrznych” (nierzadko obcych), neutralizując ich negatywny potencjał, aby skierować energię grup protestujących w pozytywnym kierunku.

Rysunek 4 przedstawia „rdzeń” tożsamości narodowej, łączący konfiguracje integrujące.

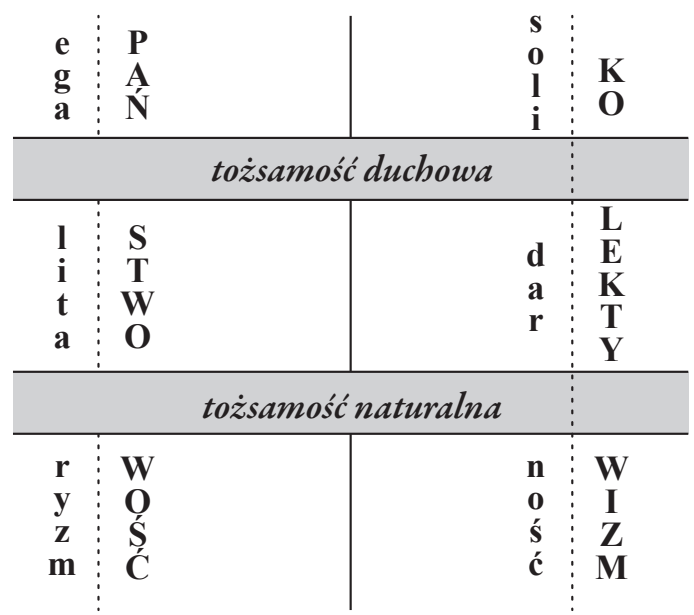

Rys. 4. „Rdzeń” aksjologiczny („pola” integrujące) rosyjskiej tożsamości narodowej

Ów „rdzeń” aksjologiczny tworzy konfigurację tożsamości, składającą się na treść patriotyzmu. Symbole patriotyzmu możemy zobaczyć w sztuce i literaturze. Szczególną rolę odgrywała również instytucja służby wojskowej - w Rosji rekruckiej, a następnie opartej na obowiązku powszechnej służby wojskowej i powinności oficera, dzięki czemu kształtowało się poczucie mocarstwowości, szacunek dla państwa, a także kolektywizm i solidarność. Powszechnie znany jest udział szkoły w kształtowaniu poczucia mocarstwowości i kolektywizmu. Tożsamość naturalna jest włączona do „rdzenia”, ponieważ patriotyzm zaszczepiany jest w rodzinie, dlatego mówi się o „rodzinnym” patriotyzmie, jak i o „kobiecym" patriotyzmie - oddaniu matek państwu, które pomaga wychowywać i kształcić dzieci (szczególnie w Rosji, gdzie rodziny niepełne z zasady tworzą matka i dzieci). 
Patriotyzm w ZSRR i w Rosji od drugiej połowy lat 80. podlegał silnej dyfamacji w kontekście liberalno-demokratycznym. Równolegle w republikach związkowych ZSRR wzmocniony został patriotyzm negatywistyczny w postaci nacjonalizmu skierowanego przeciwko ZSRR i Rosji. W XXI w. rozpoczęła się w Rosji konsekwentna praca nad odtworzeniem patriotyzmu jako „rdzenia” tożsamości narodowej. Główną rolę odgrywają tu systemy symboliczne ${ }^{13}$. Zostały ostatecznie zatwierdzone symbole państwowe (hymn, godło i flaga), przyjęto programy ich popularyzacji w szkołach, bibliotekach i mediach, programy wzmocnienia pozytywnego wizerunku Rosji w świadomości społecznej. Przywrócono parady na Placu Czerwonym z okazji Dnia Zwycięstwa 9 maja. Prowadzono prace nad korektą nastrojów nacjonalistycznych, powstrzymywano próby wzniecania nienawiści etnicznej.

Co do „otoczki” aksjologicznego „rdzenia” (patriotyzmu), to zawiera ona pozostałe „wewnętrzne” tożsamości, odznaczające się większą labilnością (elastycznością). Taka „otoczka” pozwala tworzyć modele „defensywnej” i „ofensywnej” tożsamości narodowej. Tożsamości te zajmują pozycje na obrzeżach modelu: z tożsamości społecznej (tożsamości poziome) pozostaje terytorialna i czynnościowa; z politycznej (tożsamości pionowe) - prywatna i internacjonalna („otoczka” przypomina „ramę”). Owe tożsamości poprzez interakcję z tożsamościami „zewnętrznymi” powstrzymują wpływ tych ostatnich na „rdzeń” aksjologiczny:

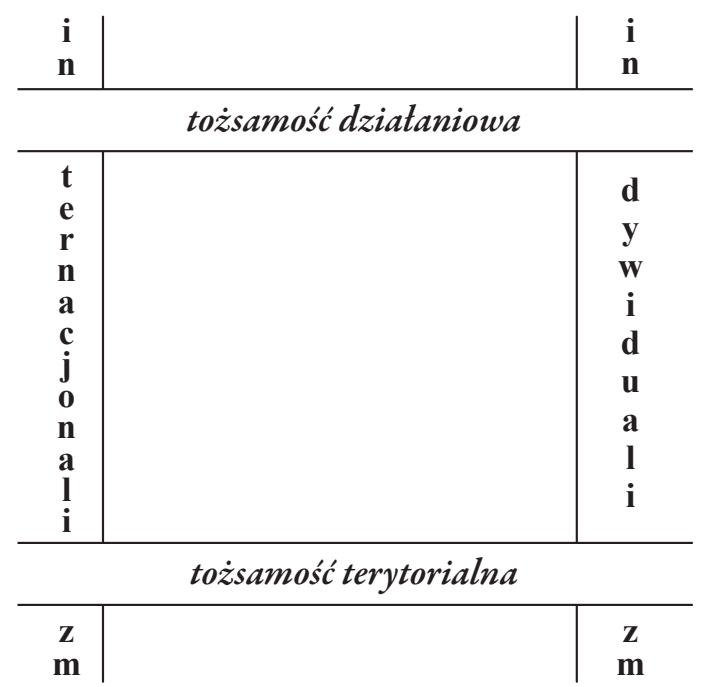

Rys. 5. „Otoczka” rosyjskiej tożsamości narodowej skorelowana $\mathrm{z}$,rdzeniem” aksjologicznym (patriotyzmem)

Zaprezentowany kognitywny model tożsamości narodowej przedstawia skomplikowaną konfigurację tożsamości „wewnętrznych”, współdziałających z tożsamo-

13 Pог. В. Капицын, Символьные комплексы: роль в институционализации и легитимации науиональньх интересов, „Пространство и время” 2013, nr 3. 
ściami „zewnętrznymi”. Mogą przy tym powstawać konfiguracje niszczące tożsamość narodową, a wraz z nią sterowność w społeczeństwie. Konfiguracje te określiliśmy mianem negatywnych kontrtożsamości. Bez odpowiedniej pracy w zakresie kształtowania patriotyzmu może zwiększać się wpływ kontrtożsamości, które są kultywowane przez niektóre grupy w celu zaszczepienia wartości obcych. W takim kierunku mogą działać tożsamości „zewnętrzne” (kosmopolityczne). Prowadzi to do „przekształcenia otoczki”, gdy w świadomości i nieświadomości ludzi indoktrynowane są wartości obce ${ }^{14}$.

Niektóre oficjalne instancje Rady Europy usiłują rekomendować eliminację dyskryminacji genderowej w tradycyjnych rodzinach, ograniczeń statusu rodzin homoseksualnych, ich prawa do wychowywania dzieci. To szereg przedsięwzięć związanych z systemem ochrony praw dziecka, zderzanych z tradycjami Rosji ${ }^{15}$. Rosji i innym krajom postradzieckim rekomenduje się zezwalanie na parady gejów ${ }^{16}$, rezygnację ze świąt, które apoteozują totalitaryzm (przeszłość radziecką) ${ }^{17}$. Wszystko to może wpłynąć na zmniejszenie liczby małżeństw i urodzeń, wzrost liczby rozwodów. W obliczu napływu emigrantów innych narodowości pojawia się problem zachowania rosyjskiej tożsamości narodowej. Negatywny wpływ ma także lokowanie środków finansowych w rajach podatkowych (оффморизащия), rezydencjalizm zewnętrzny (nabywanie praw własności, płacenie podatków za granicą), uchylanie się od służby wojskowej, uzyskiwanie wielu obywatelstw narodowo-państwowych, fikcyjne małżeństwa z cudzoziemcami, odmiany hedonizmu, prowadzące do pozorowania aktywności, traktowania realności jak gry, przejawiające się w takich negatywnych aspektach jak poszukiwanie szybkiego dochodu dzięki grom hazardowym, oszustwom i innym przestępstwom, a nie w wyniku stałej pracy zawodowej ${ }^{18}$. Swój udział ma również wpływ lokalnego etnizmu i nacjonalizmu etnicznego.

14 Por. В. М. Капицын, Идентичность и целостность российского общества, [w:] Гражданин. Общество. Государство: Россия в XXI веке, red. В. М. Капицын, Москва 2014, s. 113-116.

15 Pог. Проект рекомендащий по правам и юридиескому статусу детей и родительских обязанностей CJ-FA, GT3 (2010) 2 rev. 5 и Пояснительный меморандум к нему, CJ-FA, GT3 (2010) 2 rev. 5 , направмяемые в Комитет министров Совета Европы. Wspomniane dokumenty zostały poddane ostrej krytyce przez organizacje społeczne w Rosji i w innych krajach Europy.

16 Рекомендация Ассамблеи Парламентской Ассамблеи Совета Европы 1474 „O положении лесбиянок и гомосексуалистов в государствах-членах Совета Европь" (по докладу Комиссии по юридическим вопросам и правам человека). Принята на 27-ом заседании Ассамблеи ПАСЕ 26 сентября 2000 года.

17 Резолюиия Парламентской Ассамблеи ОБСЕ „Воссоединение разделенной Европь: поотрение прав человека и гражданских свобод в регионе ОБСЕ в ХХІ веке” (Вильнюс, 29 июня - 3 июля 2009 zoda). W punkcie 14 Rezolucji wskazano, że Zgromadzenie zwraca się z prośba do rząów i parlamentów państw-cztonków o catkowite wyeliminowanie struktur i modeli zachowania, których celem jest upiększanie przesztości, próba powrotu do niej lub dążenie do jej kontynuacji w przysztości, stanowiąc przeszkodę dla petnej demokratyzacji.

18 С. А. Кравченко, Нелинейная социокультурная динамика: играизаиионный подход, Москва 2006; С. А. Кравченко, Играизачия российского общества: блага и проблемьь, [w:] Сборник научно-nопулярных статей, wyd. 11, Москва 2008, s. 270-276; О. В. Понукалина, Игры общества 
Negatywny skutek mogą mieć przypadki dewaluacji wartości obywatelstwa narodowego i integralności społeczeństwa, aż do żądań separatystycznych. Kontrtożsamości prowadzą do odchyleń od stanu stabilności, żywiołowych protestów, które mogą przekształcać się w bunty, zamieszki na dużą skalę. Wszystko to stanowi świadectwo przekształcenia się w świadomości i nieświadomości ludzi „otoczki” tożsamości narodowej (postradzieckiej), co znajduje odzwierciedlenie na rys. 6.

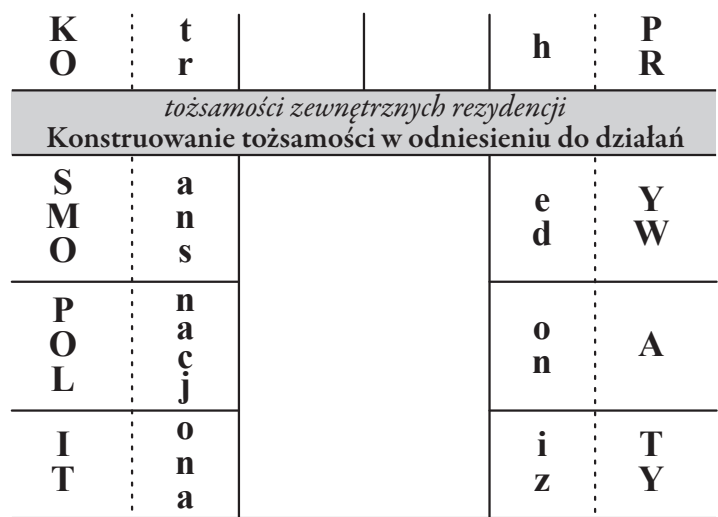

Konstruowanie tożsamości w odniesieniu do terytorium tożsamości etnizmu, nacjonalizmu etnicznego, migracyjne i in.

\begin{tabular}{l:c|l|l|l:c}
$\mathbf{Y}$ & $\mathbf{l}$ & & & $\mathbf{m}$ & $\mathbf{Z}$ \\
$\mathbf{Z}$ & $\mathbf{i}$ & & & & $\mathbf{M}$ \\
$\mathbf{M}$ & $\mathbf{Z}$ & & & &
\end{tabular}

Rys. 6. Przekształcenie „otoczki” tożsamości narodowej (postradzieckiej)

Konsekwencjami przekształcenia „otoczki”, a następnie uszkodzenia „rdzenia” były wydarzenia na rosyjskim Kaukazie Północnym w latach 1990-2000. Do głosu doszła tu tożsamość terytorialna, która przekształciła się w etnizm, co doprowadziło do eskalacji separatyzmu i ekstremizmu, eksodusu ludności rosyjskiej, secesji i wojny z państwem rosyjskim, co udało się przezwyciężyć dopiero na początku XXI w. Charakterystyczne są wydarzenia w sąsiednim państwie - na Ukrainie, gdzie na obszarach wschodnich i południowych wciąż utrzymują się „ogniska” tożsamości radzieckiej, ale jednocześnie wyraz tożsamości terytorialnej i duchowej w zachodnich regionach przekształcił się w etnizm i nacjonalizm etniczny, aż do usprawiedliwienia i apoteozy Stepana Bandery i dywizji SS „Galizien”. Taki nacjonalizm etniczny ogarnął świadomość znacznej części młodzieży z zachodnich regionów Ukrainy. Zaskakujący jest fakt, że na tym etapie masowych fluktuacji, zwłaszcza w świadomości mieszkańców Ukrainy zachodniej, nacjonalizm etniczny (w „otoczce ochronnej”) w zadziwiający sposób koegzystuje z transnacjonalizmem (dążeniem do integracji z Europą - hasła „Ukraina to Europa!”).

потребления: конструирование повседневности, „Вестник Саратовского государственного технического университета” 2009, t. 3, nr 1, s. 293-299. 
Jakie stanowisko zajmie Unia Europejska i Rosja wobec takiej symbiozy („mieszanki wybuchowej”) - to już zupełnie inna kwestia, której rozstrzygnięcie w dużym stopniu odbije się m.in. na przemianach rosyjskiej i ukraińskiej tożsamości postradzieckiej.

Thumaczenie: Magdalena Romanowska

\section{BIBLIOGRAFIA}

Акмалова А. А., Особенности правового регулирования и организачии местного самоуправления в Российской Федерации (теоретико-методологический аспект). Аиссертация на соискание степени доктора юридических наук, Москва 2003.

Анастасьев А., Повесть о рыббаках и рыєбе, „GEO. Неопознанный мир: земля” 2013, nr 11.

Гегель Г. В. Ф., Работы разных лет, т. 2, Москва 1971.

Капицын В. М., Идентичность и щелостность российского общества, [w:] Гражданин. Общество. Государство: Россия в XXI веке, red. В. М. Капицын, Москва 2014.

Капицын В. М., Символьньге комплексь: роль в институщионализации и легитимащии национальнысх интересов, „Пространство и время” 2013, nr 3.

Кравченко С. А., Играизащия российского общества: блага и проблемьи, [w:] Сборник науино-популярныцх статей, wyd. 11, Москва 2008.

Кравченко С. А., Нелинейная социокультурная динамика: играизащионный подход, Москва 2006.

Кравченко С. А., Социологический энииклопедический русско-английский словарь, Москва 2004.

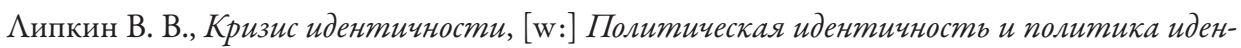
тичности. В 2-х томах, red. И. С. Семененко, t. 1: Идентичность как категорий политической науки. Словарь терминов и понятий, Москва 2012.

Аысак И. В., Наливайченко И. В., Патриотизм: отживщал ценность или актуальный тренд, Таганрог 2013.

Политическая идентичность и политика идентичности. В 2-х томах, red. И. С. Семененко, t. 1: Идентичность как категория политической науки. Словарь терминов и понятий, Москва 2012.

Понторо М.-К., Европейская Конститущия и нащиональныце конституционнье идентичности (Реферат), [w:] Конституционная культура. Универсальньье цеенности и национальныце особенности. Сб. научнысх трудов, Москва 2011.

Понукалина О. В., Игры общества потребления: конструирование повседневности, „Вестник Саратовского государственного технического университета" 2009, t. 3, nr 1.

Попов М. М., Москва рекламная, „Московский журнал истории государства российского” 2014, nr 11.

Проект рекомендащий по правам и юридическому статусу детей и родительских обязанностей CJ-FA, GT3 (2010) 2 rev. 5 и Пояснительный меморандум к нему, CJ-FA, GT3 (2010) 2 rev. 5, направмяемые в Комитет министров Совета Европы.

Резолюция Парламентской Ассамбкеи ОБСЕ Воссоединение разделенной Европь: поомре- 
ние прав человека и гражданских свобод в регионе ОБСЕ в ХХІ веке (Вимьнюс, 29 июня - 3 июля 2009 года).

Рекомендация Ассамблеи Парламентской Ассамблеи Совета Европы 1474 O положении лесбиянок и гомосексуалистов в государствах-членах Совета Европь (по докмаду Комиссии по юридическим вопросам и правам человека). Принята на 27-ом заседании Ассамблеи ПАСЕ 26 сентября 2000 года.

Эриксон Э. Г., Молодой Аютер, Москва 2004.

Ян Э., Государственная трансформачия на востоке Европь, [w:] Национализм в позднеи посткоммунистической Европе, red. Э. Ян, Москва 2010.

Władimir Michajłowicz KAPICYN - doktor habilitowany w zakresie nauk politycznych, profesor w Katedrze Politologii Porównawczej na Wydziale Politologii Moskiewskiego Uniwersytetu Państwowego im. M. Łomonosowa. 